\title{
ANALISIS SELF ESTEEM DAN PERSEPSI MAHASISWA PADA BAHASA INGGRIS TERHADAP KEMAMPUAN BERBAHASA INGGRIS MAHASISWA PROGRAM UNGGULAN POLITEKNIK NEGERI JEMBER
}

Oleh :

SITI AISYIYAH *)

\begin{abstract}
ABSTRAK
Seiring dengan perkembangan teknologi pada era global, kebutuhan akan penguasaan Bahasa Inggris sebagai bahasa internasional semakin meningkat. Merespon kondisi tersebut, Politeknik Negeri Jember (POLIJE) membekali lulusannya dengan keterampilan yang tidak hanya berkaitan dengan disiplin ilmu, tetapi juga dengan keterampilan berbahasa Inggris. Namun, sejauh ini tingkat keterampilan berbahasa Inggris para lulusan POLIJE belum memuaskan. Dua faktor yang diduga memberikan kontribusi antara lain self esteem dan persepsi mahasiswa pada Bahasa Inggris. Berdasarkan kondisi tersebut, peneliti bermaksud menguji apakah terdapat pengaruh self esteem dan persepsi mahasiswa pada Bahasa Inggris baik secara parsial maupun bersama-sama terhadap kemampuan berbahasa Inggris mahasiswa Politeknik Negeri Jember. Data penelitian ini dikumpulkan dengan menggunakan kuesioner untuk variabel bebas, dan tes international TOEIC untik variabel terikat dari 50 sampel yang diambil secara acak. Data yang diperoleh dianalisis secara deskriptif dan inferensial. Dari analisis data, diperoleh hasil sebagai berikut: (1) tidak terdapat pengaruh dari self esteem terhadap kemampuan berbahasa Inggris mahasiswa, (2) terdapat pengaruh yang signifikan dari persepsi mahasiswa terhadap kemampuan berbahasa Inggris mahasiswa, (3) terdapat pengaruh yang signifikan secara bersama-sama dari self esteem dan persepsi mahasiswa terhadap kemampuan berbahasa Inggris mahasiswa. Penelitian ini diharapkan dapat memberi masukan bagi upaya peningkatan kemampuan berbahasa Inggris mahasiswa POLIJE dalam rangka menuju world class university.
\end{abstract}

Kata kunci: Kemampuan Berbahasa Inggris, Self Esteem, Persepsi Mahasiswa

\section{PENDAHULUAN}

Seiring dengan perkembangan teknologi pada era global, kebutuhan akan penguasaan Bahasa Inggris sebagai bahasa internasional semakin meningkat. Saat ini, Bahasa Inggris menjadi jembatan menuju dunia internasional di berbagai bidang seperti pendidikan, ilmu pengetahuan, perdagangan, politik, pariwisata, dan bidang-bidang lain (Edge, 1999).

Merespon kondisi tersebut, Politeknik Negeri Jember (POLIJE) membekali lulusannya dengan keterampilan yang tidak hanya berkaitan dengan disiplin ilmu, tetapi juga dengan keterampilan berbahasa Inggris. Mata kuliah Bahasa Inggris diajarkan di seluruh program studi yang ada. Bahkan, khusus untuk mahasiswa Program Unggulan, POLIJE mewajibkan lulusannya memiliki sertifikat international TOEIC (Test of English for International Communication). TOEIC merupakan tes berstandar internasional yang digunakan untuk mengukur kemampuan berbahasa Inggris seseorang di dunia kerja. Tes tersebut sangat sesuai diterapkan pada mahasiswa POLIJE yang merupakan calon lulusan yang siap kerja.
Namun, sejauh ini tingkat keterampilan berbahasa Inggris para lulusan POLIJE belum memuaskan. Hal ini perlu mendapat perhatian yang serius mengingat Bahasa Inggris saat ini merupakan kebutuhan yang sifatnya krusial. Akan tetapi seringkali terjadi, mahasiswa yang belajar berbicara dalam Bahasa Inggris menjadi bahan olok-olok oleh teman-temannya. Apalagi jika mahasiswa tersebut melakukan kesalahan, pasti menjadi bahan tertawaan oleh teman-temannya. Kondisi seperti ini sangat tidak menguntungkan bagi proses belajar mahasiswa. Mahasiswa yang menjadi bahan olokolok atau tertawaan akan mengalami gangguan pada self esteem (harga diri) mahasiswa. Perilaku mengolok-olok atau menertawakan tersebut dapat dikategorikan sebagai tindakan bullying. Hasil penelitian Khairiah (2012) menunjukkan bahwa terdapat korelasi positif antara bullying dengan tingkat self esteem mahasiswa. Kebanyakan korban bullying mengalami penurunan self esteem. Berdasarkan hal tersebut, diduga terdapat pengaruh tingkat self esteem mahasiswa terhadap kemampuan berbahasa Inggris mahasiswa.Di samping itu, ada salah satu fenomena dalam proses pembelajaran Bahasa Inggris di POLIJE yang perlu dicermati. Karena merupakan bahasa asing, sebagian besar 
mahasiswa menganggap bahwa belajar Bahasa Inggris itu sulit. Bahkan sebagian dosen di POLIJE sendiri menganggap bahwa persyaratan kelulusan mahasiswa yang berupa sertifikasi kemampuan berbahasa Inggris merupakan hal yang mempersulit, memberatkan dan mengada-ada. Jika dosennya saja memiliki anggapan demikian, apalagi mahasiswanya. Hal ini berarti bahwa mahasiswa memiliki persepsi yang tidak baik pada Bahasa Inggris. Persepsi ini juga diduga dapat mempengaruhi hasil belajar Bahasa Inggris mahasiswa. Berdasarkan uraian tersebut, peneliti bermaksud menguji apakah terdapat pengaruh self esteem dan persepsi mahasiswa pada Bahasa Inggris baik secara parsial maupun bersama-sama terhadap kemampuan berbahasa Inggris mahasiswa Program Unggulan Politeknik Negeri Jember.

Mengingat adanya keterbatasan peneliti, masalah dalam penelitian ini dibatasi pada pengaruh self esteem dan persepsi mahasiswa pada Bahasa Inggris baik secara parsial maupun bersama-sama terhadap kemampuan berbahasa Inggris (khususnya kemampuan receptive yaitu listening dan reading) mahasiswa Program Unggulan Politeknik Negeri Jember. Tujuan dari penelitian ini adalah untuk mengetahui pengaruh self esteem dan persepsi mahasiswa pada Bahasa Inggris terhadap kemampuan berbahasa Inggris mahasiswa Program Unggulan Politeknik Negeri Jember baik secara parsial maupun secara bersama-sama.

Keterampilan berbahasa Inggris meliputi membaca (reading), menyimak (listening), menulis (writing), dan berbicara (speaking). Keterampilan berbahasa Inggris tersebut dapat diklasifikasikan ke dalam dua kelompok yaitu receptive skills yang meliputi listening dan reading, serta productive skills yang meliputi speaking dan writing (Edge, 1999).

Self esteem merupakan penilaian seseorang terhadap dirinya sendiri, baik berupa penilaian negatif maupun penilaian positif yang akhirnya menghasilkan perasaan yang membawa kepercayaan diri dalam mejalani kehidupan (Prasetya, 2013). Mellia (2007) menyebutkan bahwa self-esteem merupakan proses evaluasi diri seseorang terhadap kualitas-kualitas dalam dirinya dan terjadi terus menerus dalam diri manusia.

Menurut Thanasoulas (2008), self-esteem merupakan penilaian pribadi berupa penghargaan terhadap diri sendiri. Kurangnya self-esteem dapat menimbulkan sikap negatif terhadap kemampuannya sebagai peserta didik, dan menyebabkan menurunnya kemampuan kognitifnya, sehingga menyebabkan peserta didik yang bersangkutan menganggap dirinya tidak mampu belajar. Sementara itu, Reasoner (1982) yang dikutip oleh Riksayustiana (2008) mengemukakan lima aspek self esteem (Riksayustiana, 2008). Aspek-aspek tersebut antara lain:

1) Sense of Security, yaitu sejauh mana individu merasa aman dalam bertingkah laku karena mengetahui apa yang diharapkan oleh orang lain dan tidak takut disalahkan.

2) Sense of Identity, yaitu kesadaran individu tentang sejauh mana potensi, kemampuan dan keberartian tentang dirinya sendiri.

3) Sense of Belonging, yaitu perasaan yang muncul karena individu merasa sebagai bagian dari kelompoknya, merasa dirinya penting dan dibutuhkan oleh orang lain, dan merasa dirinya dierima oleh kelompoknya

4) Sense of Purpose, yaitu keyakinan individu bahwa dirinya akan berhasil mencapai tujuan yang diinginkannya, merasa memiliki motivasi.

5) Sense of Personal Competence, yaitu kesadaran individu bahwa dia dapat mengatasi segala tantangan dan masalah yang dihadapi dengan kemampuan, usaha, serta caranya sendiri.

Braden (1969) yang dikutip oleh Kendra Cherry (2013) menyebutkan bahwa ada 3 komponen utama self-esteem, seperti tercantum di bawah ini:

1. Self-esteem merupakan kebutuhan yang sangat essensial bagi perkembangan manusia yang normal, berdaya saing, dan sehat.

2. Self-esteem muncul secara otomatis dari dalam diri seseorang berdasarkan keyakinan dan kesadarannya.

3. Self-esteem muncuh sesuai dengan pikiran, perilaku, perasaan, dan tindakan seseorang.

Persepsi (dari bahasa Latin perceptio, percipio) adalah tindakan menyusun, mengenali, dan menafsirkan informasi sensoris guna memberikan gambaran dan pemahaman tentang lingkungan (Schacter, 2011). Sutisna (2001) yang dikutip oleh Muntamah.,dkk. (2012) menyebutkan bahwa persepsi seseorang terhadap suatu obyek akan berbeda-beda, oleh karena itu persepsi mempunyai sifat yang subyektif.

Faktor-faktor yang mempengaruhi persepsi pada dasarnya dibagi menjadi 2 yaitu faktor internal dan faktor eksternal (Anonymous, 2013).

a. Faktor internal yang mempengaruhi persepsi, yaitu faktor-faktor yang terdapat dalam diri individu, yang mencakup beberapa hal antara lain :

- Fisiologis

Informasi masuk melalui alat indera, selanjutnya informasi yang diperoleh ini akan mempengaruhi dan melengkapi usaha untuk memberikan arti terhadap lingkungan sekitarnya.

- Perhatian 
Individu memerlukan sejumlah energi yang dikeluarkan untuk memperhatikan atau memfokuskan pada bentuk fisik dan fasilitas mental yang ada pada suatu obyek.

- Minat

Persepsi terhadap suatu obyek bervariasi tergantung pada seberapa banyak energi atau perceptual vigilance yang digerakkan untuk mempersepsi. Perceptual vigilance merupakan kecenderungan seseorang untuk memperhatikan tipe tertentu dari stimulus atau dapat dikatakan sebagai minat.

- Kebutuhan yang searah

Faktor ini dapat dilihat dari bagaimana kuatnya seseorang individu mencari obyekobyek atau pesan yang dapat memberikan jawaban sesuai dengan dirinya.

- Pengalaman dan ingatan

Pengalaman dapat dikatakan tergantung pada ingatan dalam arti sejauh mana seseorang dapat mengingat kejadian-kejadian lampau untuk mengetahui suatu rangsang dalam pengertian luas.

- Suasana hati

Keadaan emosi mempengaruhi perilaku seseorang, mood ini menunjukkan bagaimana perasaan seseorang pada waktu yang dapat mempengaruhi bagaimana seseorang dalam menerima, bereaksi dan mengingat.

b. Faktor eksternal yang mempengaruhi persepsi, merupakan karakteristik dari linkungan dan obyek-obyek yang terlibat didalamnya. Faktorfaktor eksternal yang mempengaruhi persepsi adalah :

- Ukuran dan penempatan dari obyek atau stimulus

Faktor ini menyatakan bahwa semakin besrnya hubungan suatu obyek, maka semakin mudah untuk dipahami.

- Warna dari obyek-obyek

Obyek-obyek yang mempunyai cahaya lebih banyak, akan lebih mudah dipahami (to be perceived) dibandingkan dengan yang sedikit.

- Keunikan dan kekontrasan stimulus

Stimulus luar yang penampilannya dengan latarbelakang dan sekelilingnya yang sama sekali di luar sangkaan individu yang lain akan banyak menarik perhatian.

- Intensitas dan kekuatan dari stimulus

Stimulus dari luar akan memberi makna lebih bila lebih sering diperhatikan dibandingkan dengan yang hanya sekali dilihat.

- Motion atau gerakan

Individu akan banyak memberikan perhatian terhadap obyek yang memberikan gerakan dalam jangkauan pandangan dibandingkan obyek yang diam.

Berdasarkan uraian di atas, hipotesis penelitian ini adalah: (1) Terdapat pengaruh self esteem mahasiswa terhadap kemampuan berbahasa Inggris mahasiswa, (2) Terdapat pengaruh persepsi mahasiswa pada Bahasa Inggris terhadap kemampuan berbahasa Inggris mahasiswa, dan (3) Terdapat pengaruh self esteem dan persepsi mahasiswa pada Bahasa Inggris secara bersamasama terhadap kemampuan berbahasa Inggris mahasiswa.

\section{METODOLOGI PENELITIAN}

Tujuan operasional dari penelitian ini adalah untuk mengetahui apakah terdapat pengaruh self esteem dan persepsi mahasiswa pada Bahasa Inggris baik secara parsial maupun bersama-sama terhadap kemampuan berbahasa Inggris mahasiswa. Tempat penelitian adalah Politeknik Negeri Jember. Waktu penelitian adalah pada semester gasal tahun akademik 2014/2015.

Penelitian ini adalah penelitian kuantitatif yang menggunakan metode survei. Hal ini berarti penelitian ini dimaksudkan untuk membuktikan adanya pengaruh self esteem dan persepsi mahasiswa pada Bahasa Inggris terhadap kemampuan berbahasa Inggris mahasiswa baik secara parsial maupun bersama-sama. Dalam hal ini, variabel bebasnya adalah self esteem dan persepsi mahasiswa pada Bahasa Inggris, sedangkan variabel terikat adalah kemampuan berbahasa Inggris mahasiswa.

Populasi target dari penelitian ini adalah seluruh mahasiswa Program Unggulan Politeknik Negeri Jember tahun akademik 2014/2015. Populasi terjangkau adalah mahasiswa semester akhir Program Unggulan Politeknik Negeri Jember tahun akademik 2014/2015. Mahasiswa semester akhir dipilih dengan pertimbangan mereka sudah selesai menempuh mata kuliah Bahasa Inggris dan mendapatkan pelatihan persiapan tes TOEIC, sehingga mereka memiliki bekal yang cukup untuk mengikuti tes international TOEIC.

Sampel dalam penelitian ini diambil secara acak dari semua konsentrasi pada Program Unggulan Politeknik Negeri Jember. Jumlah sampel yang dipilih sebanyak 50 orang dari total jumlah mahasiswa program unggulan semester akhir sebanyak 93 mahasiswa. Ukuran sampel ini sudah memenuhi persyaratan untuk melakukan penelitian. Hal ini sesuai dengan pendapat Sugiyono (2006) yang menyatakan bahwa ukuran sampel yang layak dalam penelitian adalah antara 
30 sampai dengan 500. Selain itu, untuk penelitian dengan analisis multivariat, jumlah sampel minimal 10 kali dari jumlah variabel yang diteliti (Sugiyono, 2006). Variabel yang diteliti dalam penelitian ini sebanyak 3 variabel $(1$ variabel terikat dan 2 variabel bebas), sehingga jumlah sampel minimal adalah $3 \times 10=30$. Jumlah sampel dalam penelitian ini sudah memenuhi syarat kelayakan, sehingga dapat digunakan dalam penelitian.

Menurut Arikunto (2007), teknik pengumpulan data adalah cara-cara yang digunakan oleh peneliti untuk mengumpulkan data, sedangkan instrumen penelitian adalah alat bantu yang dipilih dan digunakan oleh peneliti dalam kegiatan mengumpulkan data agar kegiatan tersebut menjadi sistematis dan lebih mudah. Dalam penelitian ini, teknik pengumpulan data dilakukan dengan menggunakan instrumen berupa kuesioner dan tes.

Kuesioner yang digunakan dalam penelitian ini adalah kuesioner tertutup yang terdiri atas kuesioner self esteem mahasiswa dan kuesioner persepsi mahasiswa pada Bahasa Inggris. Sedangkan tes yang digunakan untuk mengukur tingkat kemampuan berbahasa Inggris mahasiswa adalah standardized test atau tes berstandar internasional. Standardized test merupakan tes yang biasanya digunakan di berbagai negara dengan persyaratan dan penilaian yang sama berdasarkan prosedur yang sama (Woolfolk, 2004). Tes berstandar internasional yang digunakan dalam penelitian ini adalah TOEIC (Test of English for International Communication). Jumlah item tes TOEIC sebanyak 200 butir yang terdiri atas 100 butir untuk listening comprehension section dan 100 butir untuk reading comprehension section. Seluruh butir soal berbentuk pilihan ganda (multiple choice) yang harus diselesaikan dalam waktu 120 menit dengan distribusi waktu 45 menit untuk listening comprehension section, dan 75 menit untuk reading comprehension section. TOEIC merupakan tes yang digunakan untuk mengukur kemampuan berbahasa Inggris seseorang dalam komunikasi di tempat kerja. Politeknik Negeri Jember merupakan lembaga pendidikan vokasional yang mencetak lulusan yang siap kerja. Jadi, pemilihan TOEIC untuk mengukur kemampuan berbahasa Inggris mahasiswa sangat sesuai dengan muatan kurikulum Politeknik Negeri Jember.

Data dianalisis secara deskriptif dan inferensial. Analisis deskriptif dilakukan untuk memperoleh gambaran secara umum dari hasil penelitian. Dalam tahap ini data disajikan dalam statistik deskriptif seperti perhitungan mean, median, modus, simpangan baku (standar deviasi) dan rentang teoretik masing-masing variabel.
Analisis inferensial dilakukan untuk menguji hipotesis. Sebelumnya perlu diuji persyaratan analisis data, yaitu uji normalitas dan uji homogenitas. Uji normalitas dilakukan dengan menggunakan One Sample Kolmogorov-Smirnov, sedangkan uji homogenitas dilakukan dengan menggunakan One Way Anova. Pengujian hipotesis dilakukan dengan menggunakan analisis regresi baik secara parsial maupun ganda dengan taraf siknifikan $5 \%$.

Hipotesis statistik dari penelitian ini adalah sebagai berikut:
1. $\mathrm{H}_{0}: \quad \mathrm{p}_{\mathrm{y} 1}=0$
$\mathrm{H}_{1} \quad: \quad \mathrm{p}_{\mathrm{y} 1} \neq 0$
$\mathrm{p}_{\mathrm{y} 1} \quad$ : $\quad$ koefisien regresi pengaruh self esteem mahasiswa terhadap kemampuan berbahasa Inggris mahasiswa
2. $\mathrm{H}_{0}: \quad \mathrm{p}_{\mathrm{y} 2}=0$
$\mathrm{H}_{1} \quad: \quad \mathrm{p}_{\mathrm{y} 2} \neq 0$
$\mathrm{p}_{\mathrm{y} 2}$ : koefisien regresi pengaruh
persepsi mahasiswa pada Bahasa Inggris
terhadap kemampuan berbahasa Inggris mahasiswa
3. $\mathrm{H}_{0}: \quad \mathrm{p}_{\mathrm{y} .12}=0$
$\mathrm{H}_{1} \quad: \quad p_{\mathrm{y} .12} \neq 0$
$\mathrm{p}_{\mathrm{y} .12}$ : $\quad$ koefisien regresi pengaruh self
esteem dan persepsi mahasiswa pada Bahasa
Inggris secara bersama-sama terhadap
kemampuan berbahasa Inggris mahasiswa

\section{HASIL PENELITIAN}

Data penelitian diperoleh dari 50 responden yang dipilih secara acak. Setiap responden diminta untuk menjawab butir-butir pernyataan dalam kuesioner dari tiga variabel penelitian, yaitu satu varibel terikat kemampuan berbahasa Inggris mahasiswa (Y) yang ditunjukkan dengan nilai TOEIC (Test of English for International Communication), dan dua variabel bebas yaitu self esteem $\left(\mathrm{X}_{1}\right)$ dan persepsi mahasiswa $\left(\mathrm{X}_{2}\right)$.

Untuk mendapatkan gambaran statistik dari ketiga variabel tersebut, terlebih dahulu dilakukan analisis statistik deskriptif untuk mendapatkan nilai rata-rata (mean), nilai tengah (median), nilai yang paling sering muncul (modus), simpangan baku (standar deviasi), dan varians.

Nilai kemampuan berbahasa Inggris mahasiswa (Y) yang ditunjukkan dengan nilai TOEIC (Test of English for International Communication) diperoleh dari jawaban responden terhadap 200 butir soal. Soal terdiri atas 100 soal listening comprehension dan 100 soal reading comprehension. Tes TOEIC merupakan tes berstandar internasional yang digunakan untuk mengukur kemampuan berbahasa Inggris mahasiswa dalam komunikasi internasional. Pemberian skor dilakukan dengan menggunakan 
konversi yang ditentukan oleh ETS (Education Testing Service) sebagai provider tes TOEIC.

Skor self esteem diperoleh dari jawaban responden terhadap 25 butir pernyataan dalam instrumen. Pemberian skor dilakukan dengan skala Likert dengan lima alternatif pilihan Sangat Setuju (SS), Setuju (S), Ragu-ragu (R), Tidak Setuju (TS), dan Sangat Tidak Setuju (STS). Skor terendah adalah 1 sedangkan skor tertinggi adalah 5 , sehingga rentang skor teoritik ialah 25 sampai 125.

Skor persepsi mahasiswa terhadap mata kuliah Bahasa Inggris diperoleh dari jawaban responden terhadap 25 butir pernyataan dalam instrumen. Pemberian skor dilakukan dengan skala Likert dengan lima alternatif pilihan Sangat Setuju (SS), Setuju (S), Ragu-ragu (R), Tidak Setuju (TS), dan Sangat Tidak Setuju (STS). Skor terendah adalah 1 sedangkan skor tertinggi adalah 5, sehingga rentang skor teoritik ialah 25 sampai 125 .

Hasil analisis statistik deskriptif ketiga variabel dapat dilihat pada tabel di bawah ini.

Tabel 1. Hasil Analisis Statistik Deskriptif

\begin{tabular}{|l|r|r|r|}
\hline & $\begin{array}{c}\text { Kemampuan } \\
\text { Berbahasa } \\
\text { Inggris }\end{array}$ & $\begin{array}{c}\text { Kondisi } \\
\text { Lingkungan }\end{array}$ & Motivasi \\
\hline Mean & $3.8180 \mathrm{E} 2$ & $1.0276 \mathrm{E} 2$ & $1.0214 \mathrm{E} 2$ \\
\hline Median & $3.5500 \mathrm{E} 2$ & $1.0300 \mathrm{E} 2$ & $1.0100 \mathrm{E} 2$ \\
\hline $\begin{array}{l}\text { Standar } \\
\text { Deviasi }\end{array}$ & $1.40494 \mathrm{E} 2$ & 7.77111 & 7.71696 \\
\hline Varians & $1.974 \mathrm{E} 4$ & 60.390 & 59.551 \\
\hline Rentang & 580.00 & 39.00 & 28.00 \\
\hline Min. & 200.00 & 82.00 & 88.00 \\
\hline Maks. & 780.00 & 121.00 & 116.00 \\
\hline
\end{tabular}

Pengujian persyaratan analisis yang harus dilakukan untuk menguji hipotesis dengan menggunakan analisis regresi antara lain meliputi uji normalitas dan uji heteroskedastisitas.

Pengujian persyaratan yang pertama dilakukan ialah uji normalitas pada variabel $\mathrm{Y}$, variabel $\mathrm{X}_{1}$ dan variabel $\mathrm{X}_{2}$ menggunakan uji One Sample Kolmogorov Smirnov. Sampel akan berdistribusi normal apabila didapatkan nilai Sig. > nilai taraf signifikansi $\alpha=0,05$. Sebaliknya apabila nilai Sig. < nilai taraf signifikansi $\alpha=0,05$ berarti sampel tidak berdistribusi normal.

Hasil perhitungan uji normalitas menggunakan One Sample Kolmogorov Smirnov menunjukkan nilai Asymp Sig atau $\alpha$ value = 0,228 di mana > 0,05 maka residual berdistribusi normal, sehingga dapat dilakukan pengujian hipotesis. Uji heteroskedastisitas yang disebut juga uji glejser menggunakan metode Glejser dilakukan dengan meregresikan variable-variabel bebas terhadap "Absolut Residual”. Dikatakan tidak ada gejala heteroskedastisitas, apabila tidak semua nilai Sig. t parsial < 0,05 dan Sig Uji F > 0,05. Hasil perhitungan uji heteroskedastisitas dapat dilihat pada tabel di bawah ini.

Pada awalnya, ditemukan gejala heteroskedastisitas pada data penelitian. Oleh karena terjadi masalah heteroskedastisitas maka perlu upaya untuk mengatasinya anda dengan cara melakukan transformasi Logaritma Natural pada Y. Setalah dilakukan transformasi, diperoleh hasil bahwa semua variabel independen memiliki nilai Sig > 0,05 dan Sig uji f pada table ANOVA > 0,05 maka disimpulkan bahwa tidak ada gejala heteroskedastisitas, sehingga data penelitian sudah memenuhi persyaratan untuk dilakukan uji hipotesis.

Dalam hipotesis pertama tentang pengaruh variabel self esteem $\left(\mathrm{X}_{1}\right)$ terhadap kemampuan berbahasa Inggris mahasiswa (Y) telah dikemukakan hipotesis nol $\left(\mathrm{H}_{0}\right)$ : $\mathrm{p}_{\mathrm{y} 1}=0$, dan hipotesis alternatif $\left(\mathrm{H}_{1}\right): \mathrm{p}_{\mathrm{y} 1} \neq 0$, di mana $\mathrm{p}_{\mathrm{y} 1}$ adalah pengaruh $\mathrm{X}_{1}$ terhadap $\mathrm{Y}$.

Dari hasil analisis data diperoleh harga $\mathrm{a}=$ 136,922 dan $b=2,383$ sehingga berdasarkan persamaan regresi sederhana $\mathrm{LN}(\mathrm{Y})=\mathrm{a}+\mathrm{bX} 1$ diperoleh persamaan $\mathrm{LN}(\mathrm{Y})=136,922+2,383 \mathrm{X}_{1}$. Selanjutnya dilakukan uji koefisien regresi secara parsial yang dipergunakan untuk menguji apakah koefisien regresi dari masing-masing variabel bebas yaitu self esteem $\left(\mathrm{X}_{1}\right)$ dan persepsi mahasiswa $\left(\mathrm{X}_{2}\right)$ mempunyai pengaruh secara parsial terhadap kemampuan berbahasa Inggris mahasiswa (Y). Apabila nilai sig. t lebih besar dari level of significance $(\alpha)$, maka Ho diterima dan $\mathrm{H}_{1}$ ditolak artinya variabel bebas tidak berpengaruh terhadap variabel terikat. Sebaliknya, apabila nilai probabilitas $\mathrm{t}$ lebih kecil level of significance $(\alpha)$, maka Ho ditolak dan $\mathrm{H}_{1}$ diterima artinya variabel bebas berpengaruh terhadap variabel terikat.

Dari hasil analisis regresi pada lampiran 5 dapat dilihat bahwa variabel bebas self esteem $\left(\mathrm{X}_{1}\right)$ memiliki nilai sig. $\mathrm{t}$ sebesar 0,362 yang lebih besar dari level of significance $(\alpha=0,05)$, maka Ho diterima dan $\mathrm{H}_{1}$ ditolak sehingga variabel self esteem $\left(\mathrm{X}_{1}\right)$ tidak berpengaruh secara parsial terhadap kemampuan berbahasa Inggris mahasiswa (Y).

Berdasarkan hasil analisis di atas dapat disimpulkan bahwa hipotesis alternatif $\left(\mathrm{H}_{1}\right)$ ditolak. Hal ini berarti tidak terdapat pengaruh dari Self Esteem terhadap kemampuan berbahasa Inggris mahasiswa.

Dalam hipotesis kedua tentang pengaruh variabel persepsi mahasiswa $\left(\mathrm{X}_{2}\right)$ terhadap 
kemampuan berbahasa Inggris mahasiswa (Y) telah dikemukakan hipotesis nol $\left(\mathrm{H}_{0}\right): \mathrm{p}_{\mathrm{y} 2}=0$, dan hipotesis alternatif $\left(\mathrm{H}_{1}\right): \mathrm{p}_{\mathrm{y} 2} \neq 0$, di mana $\mathrm{p}_{\mathrm{y} 2}$ adalah pengaruh $\mathrm{X}_{2}$ terhadap $\mathrm{Y}$. Berikut ini merupakan hasil analisis regresi sederhana variabel $\mathrm{X}_{2}$ terhadap $\mathrm{Y}$.

Dari hasil analisis data diperoleh harga $\mathrm{a}=$ 4,045 dan $\mathrm{b}=0,018$ sehingga berdasarkan persamaan regresi sederhana $\mathrm{LN}(\mathrm{Y})=\mathrm{a}+\mathrm{bX} 2$ diperoleh persamaan $\mathrm{LN}(\mathrm{Y})=4,045+0,018 \mathrm{X}_{2}$. Selanjutnya dilakukan uji koefisien regresi secara parsial yang dipergunakan untuk menguji apakah koefisien regresi dari masing-masing variabel bebas yaitu self esteem $\left(\mathrm{X}_{1}\right)$ dan persepsi mahasiswa $\left(\mathrm{X}_{2}\right)$ mempunyai pengaruh secara parsial terhadap kemampuan berbahasa Inggris mahasiswa (Y). Apabila nilai sig. t lebih besar dari level of significance $(\alpha)$, maka Ho diterima dan $\mathrm{H}_{1}$ ditolak artinya variabel bebas tidak berpengaruh terhadap variabel terikat. Sebaliknya, apabila nilai sig. $\mathrm{t}$ lebih kecil level of significance $(\alpha)$, maka Ho ditolak dan $\mathrm{H}_{1}$ diterima artinya variabel bebas berpengaruh terhadap variabel terikat.

Dari hasil analisis regresi dapat dilihat bahwa variabel bebas persepsi mahasiswa $\left(\mathrm{X}_{2}\right)$ memiliki nilai probabilitas $\mathrm{t}$ sebesar 0,004 yang lebih kecil dari level of significance $(\alpha=0,05)$, maka Ho ditolak dan $\mathrm{H}_{1}$ diterima sehingga variabel persepsi mahasiswa $\left(\mathrm{X}_{2}\right)$ berpengaruh secara parsial terhadap kemampuan berbahasa Inggris mahasiswa (Y).

Uji signifikansi koefisien regresi parsial dapat dilakukan dengan membandingkan nilai $t$ hitung dengan nilai $t$ tabel dengan kriteria apabila nilai $\mathrm{t}_{\text {hitung }}>$ nilai $\mathrm{t}_{\text {tabel }}$ berarti terdapat pengaruh yang signifikan. Sebaliknya jika nilai $t_{\text {hitung }}<$ nilai $t_{\text {tabel }}$ berarti pengaruh tidak signifikan. Dari hasil analisis data diperoleh nilai $t_{\text {hitung }}=3,070$ dan nilai $\mathrm{t}$ tabel pada taraf signifikansi 0,05 untuk uji 2 sisi adalah $\mathrm{t}_{\text {tabel }}=1,6779$. Nilai $\mathrm{t}_{\text {hitung }}=3,070>\mathrm{t}_{\text {tabel }}$ $=1,6779$. Hal ini berarti pengaruh persepsi mahasiswa $\left(\mathrm{X}_{2}\right)$ terhadap kemampuan berbahasa Inggris mahasiswa (Y) adalah signifikan, sehingga makin baik persepsi mahasiswa makin tinggi pula tingkat kemampuan berbahasa Inggris mahasiswa. Rangkuman hasil uji signifikansi tersebut dapat dilihat dalam tabel berikut:

Tabel 3. Hasil Uji Signifikansi Pengaruh $\mathbf{X}_{2}$ terhadap Y

\begin{tabular}{|c|c|c|c|c|}
\hline $\begin{array}{c}\text { Koef. } \\
\text { Regresi }\end{array}$ & $\begin{array}{c}\text { Koef. } \\
\text { Deter } \\
\text { minas } \\
\mathrm{i}\end{array}$ & $\mathrm{t}_{\text {hitung }}$ & $\begin{array}{c}\mathrm{t}_{\text {tabel }} \\
(\alpha=0,02 \\
5)\end{array}$ & $\begin{array}{c}\text { Kesimpul } \\
\text { an }\end{array}$ \\
\hline 0,405 & 0,164 & 3,070 & 1,6779 & $\begin{array}{c}\text { Pengaruh } \\
\text { signifikan }\end{array}$ \\
\hline
\end{tabular}

Koefisien determinasi sebesar 0,164 menunjukkan bahwa 16,4\% kemampuan berbahasa
Inggris mahasiswa ditentukan oleh persepsi mahasiswa $\left(\mathrm{X}_{2}\right)$ setelah self esteem $\left(\mathrm{X}_{1}\right)$ dikontrol.

Berdasarkan hasil analisis di atas dapat disimpulkan bahwa hipotesis alternatif $\left(\mathrm{H}_{1}\right)$ diterima. Hal ini berarti terdapat pengaruh positif dari persepsi mahasiswa terhadap kemampuan berbahasa Inggris mahasiswa.

Dalam hipotesis ketiga tentang pengaruh variabel self esteem $\left(\mathrm{X}_{1}\right)$ dan persepsi mahasiswa $\left(\mathrm{X}_{2}\right)$ terhadap kemampuan berbahasa Inggris mahasiswa (Y) telah dikemukakan hipotesis nol $\left(\mathrm{H}_{0}\right): \mathrm{p}_{\mathrm{y} .12}=0$, dan hipotesis alternatif $\left(\mathrm{H}_{1}\right): \mathrm{p}_{\mathrm{y} .12} \neq$ 0 , di mana $\mathrm{p}_{\mathrm{y} .12}$ adalah pengaruh $\mathrm{X}_{1}$ dan $\mathrm{X}_{2}$ secara bersama-sama terhadap Y. Pengujian hipotesis ketiga dilakukan dengan menggunakan analisis regresi ganda.

Berdasarkan hasil analisis data diperoleh harga $a=4,182, b_{1}=-0,002$, dan $b_{2}=0,019$, sehingga berdasarkan persamaan regresi sederhana $\mathrm{LN}(\mathrm{Y})=\mathrm{a}+\mathrm{b}_{1} \mathrm{X}_{1}+\mathrm{b}_{2} \mathrm{X}_{2}$ diperoleh persamaan $\mathrm{LN}(\mathrm{Y})=4,182-0,002 \mathrm{X}_{1}+0,019 \mathrm{X}_{2}$.

Selanjutnya dilakukan analisis regresi ganda variabel self esteem $\left(\mathrm{X}_{1}\right)$ dan persepsi mahasiswa $\left(\mathrm{X}_{2}\right)$ secara bersama-sama terhadap kemampuan berbahasa Inggris mahasiswa (Y). Dari hasil analisis diketahui bahwa probabilitas $\mathrm{F}$ sebesar 0,000 yang menunjukkan bahwa probabilitas $\mathrm{F}$ lebih kecil dari level of significance $(\alpha=0,05)$, maka Ho ditolak dan $\mathrm{H}_{1}$ diterima, yang berarti variabel self esteem $\left(\mathrm{X}_{1}\right)$ dan persepsi mahasiswa $\left(\mathrm{X}_{2}\right)$ secara bersama-sama berpengaruh terhadap kemampuan berbahasa Inggris mahasiswa (Y).

Uji signifikansi dilakukan dengan membandingkan nilai $F_{\text {hitung }}$ dengan nilai $F_{\text {tabel. }}$ Jika nilai $F_{\text {hitung }}$ lebih besar daripada nilai $F_{\text {tabel, }}$ berarti pengaruh variabel bebas terhadap variabel terikat signifikan. Dari hasil analisis data diperoleh nilai $F_{\text {hitung }}=4,696$ dan nilai $F_{\text {tabel }}$ pada taraf signifikasi $5 \%$ adalah 3,23. Nilai $F_{\text {hitung }}=$ $4,696>\mathrm{F}_{\text {tabel }}=3,23$ berarti regresi $\mathrm{Y}$ atas $\mathrm{X}_{1}$ dan $\mathrm{X}_{2}$ adalah signifikan. Dengan demikian dapat disimpulkan bahwa pengaruh self esteem $\left(\mathrm{X}_{1}\right)$ dan persepsi mahasiswa $\left(\mathrm{X}_{2}\right)$ secara bersama-sama terhadap kemampuan berbahasa Inggris mahasiswa (Y) adalah signifikan. Rangkuman hasil uji signifikansi tersebut dapat dilihat pada tabel berikut ini:

Tabel 4. Hasil Uji Signifikansi Pengaruh $\mathrm{X}_{1}$ dan $\mathrm{X}_{2}$ terhadap $\mathrm{Y}$

\begin{tabular}{|c|c|c|c|c|}
\hline $\begin{array}{c}\text { Koef. } \\
\text { Regresi }\end{array}$ & $\begin{array}{c}\text { Koef. } \\
\text { Determinasi }\end{array}$ & $\mathrm{F}_{\text {hitung }}$ & $\begin{array}{c}\mathrm{F}_{\text {tabel }} \\
\alpha= \\
0,05\end{array}$ & Kesimpulan \\
\hline 0,408 & 0,131 & 4,696 & 3,23 & $\begin{array}{c}\text { Pengaruh } \\
\text { signifikan }\end{array}$ \\
\hline
\end{tabular}

Dari tabel diketahui nilai koefisien regresi ganda $\mathrm{R}_{\mathrm{Y} .12}=0,408$ dan koefisien determinasi $\mathrm{R}^{2} \mathrm{Y} .12=0,131$. Koefisien determinasi sebesar 0,131 menunjukkan bahwa $13,1 \%$ kemampuan 
berbahasa Inggris mahasiswa ditentukan oleh self esteem dan persepsi mahasiswa mahasiswa secara bersama-sama. Nilai koefisien yang positif menunjukkan arah pengaruh yang positif pula.

Berdasarkan hasil analisis di atas dapat disimpulkan bahwa hipotesis alternatif $\left(\mathrm{H}_{1}\right)$ diterima. Hal ini berarti terdapat pengaruh yang signifikan dan positif dari self esteem dan persepsi mahasiswa secara bersama-sama terhadap kemampuan berbahasa Inggris mahasiswa. Artinya semakin tinggi tingkat self esteem yang diikuti dengan persepsi mahasiswa yang semakin baik, maka semakin tinggi pula kemampuan berbahasa Inggris mahasiswa.

\section{PEMBAHASAN}

Berdasarkan pengujian hipotesis yang dilakukan terhadap data hasil penelitian, diketahui bahwa hanya hipotesis kedua dan ketiga yang diajukan dalam penelitian ini teruji kebenarannya. Variabel bebas self esteem tidak memberikan pengaruh terhadap variabel terikat yaitu kemampuan berbahasa Inggris mahasiswa secara parsial. Sedangkan variabel bebas persepsi mahasiswa berpengaruh signifikan terhadap kemampuan berbahasa Inggris mahasiswa secara parsial. Selanjutnya, variabel bebas self esteem dan persepsi mahasiswa secara bersama-sama juga berpengaruh signifikan terhadap kemampuan berbahasa Inggris mahasiswa. Selanjutnya pengaruh variabel bebas dan variabel terikat tersebut dapat dijelaskan sebagai berikut.

Dari hasil analisis data ditemukan bahwa tidak terdapat pengaruh self esteem terhadap kemampuan berbahasa Inggris mahasiswa. Hal ini dapat dipahami bahwa ada banyak faktor lain yang dapat mempengaruhi keberhasilan belajar mahasiswa, antara lain motivasi, kondisi lingkungan belajar, atau tingkat intelegensi mahasiswa. Namun demikian hal ini tidak berarti bahwa faktor self esteem dapat diabaikan, karena setiap kondisi psikologis yang positif akan memberikan dampak yang baik pada setiap individu. Hal ini dapat dilihat pada uji hipotesis ketiga di mana faktor self esteem secara bersamasama dengan faktor persepsi memberikan pengaruh yang signifikan terhadap kemampuan berbahasa Inggris mahasiswa. Self esteem berkaitan dengan emosi atau perasaan individu tentang dirinya sendiri atau evaluasi tentang dirinya sendiri (Schunk , 2012). Kondisi ini berpengaruh pada minat individu untuk mempelajari Bahasa Inggris. Faktor minat inilah yang perlu ditumbuhkan agar mahasiswa mau mempelajari Bahasa Inggris dengan sungguhsungguh untuk meningkatkan keterampilan berkomunikasi.

Dari hasil analisis data terlihat adanya pengaruh persepsi mahasiswa $\left(\mathrm{X}_{2}\right)$ terhadap kemampuan berbahasa Inggris mahasiswa (Y) yang cukup berarti pada taraf signifikansi $\alpha=0,05$ dengan persamaan regresi linier $\mathrm{LN}(\mathrm{Y})=4,045+$ $0,018 \mathrm{X}_{2}$. Ini berarti bahwa setiap kenaikan satu skor pada persepsi mahasiswa diikuti oleh kenaikan 0,018 skor kemampuan berbahasa Inggris mahasiswa pada konstanta 4,045.

Adapun koefisien regresi persepsi mahasiswa terhadap kemampuan berbahasa Inggris mahasiswa adalah $r_{\mathrm{y} 2}=0,405$ dan koefisien determinasi $r^{2}{ }^{2}=$ 0,164 yang telah teruji signifikan sehingga dapat diartikan bahwa variabel persepsi mahasiswa sangat berpengaruh terhadap kemampuan berbahasa Inggris mahasiswa sebesar 16,4\%.

Dengan demikian dapat disimpulkan bahwa persepsi mahasiswa yang baik dapat meningkatkan tingkat kemampuan berbahasa Inggris mahasiswa. Demikian pula sebaliknya, persepsi mahasiswa yang buruk dapat menurunkan tingkat kemampuan berbahasa Inggris mahasiswa.

Dari hasil analisis data terlihat adanya pengaruh self esteem $\left(\mathrm{X}_{1}\right)$ dan persepsi mahasiswa $\left(\mathrm{X}_{2}\right)$ secara bersama-sama terhadap kemampuan berbahasa Inggris mahasiswa (Y) cukup berarti pada taraf signifikansi $\alpha=0,05$ dengan persamaan regresi linier $\mathrm{LN}(\mathrm{Y})=4,182-0,002 \mathrm{X}_{1}+0,019 \mathrm{X}_{2}$. Ini berarti bahwa kenaikan skor pada self esteem dan skor pada persepsi mahasiswa diikuti oleh kenaikan skor kemampuan berbahasa Inggris mahasiswa pada konstanta 4,182.

Adapun koefisien regresi self esteem $\left(\mathrm{X}_{1}\right)$ dan persepsi mahasiswa $\left(\mathrm{X}_{2}\right)$ secara bersama-sama terhadap kemampuan berbahasa Inggris mahasiswa (Y) adalah $\mathrm{R}_{\mathrm{Y} .12}=0,408$ dan koefisien determinasi $\mathrm{R}^{2} \mathrm{Y} .12=0,131$ telah teruji signifikan sehingga dapat diartikan bahwa variabel self esteem dan persepsi mahasiswa secara bersama-sama berpengaruh terhadap kemampuan berbahasa Inggris mahasiswa sebesar 13,1\%. Hal ini menunjukkan bahwa persentase sumbangan pengaruh variabel self esteem dan persepsi mahasiswa terhadap kemampuan berbahasa Inggris mahasiswa sebesar $13,1 \%$. Sedangkan sisanya $86,9 \%$ dipengaruhi oleh variabel lain yang tidak dimasukkan dalam penelitian ini.

Berdasarkan hasil analisis tersebut dapat dilihat bahwa makin tinggi tingkat self esteem yang diikuti oleh persepsi mahasiswa yang baik maka kemampuan berbahasa Inggris mahasiswa akan semakin tinggi. Demikian pula sebaliknya, 
makin rendah tingkat self esteem yang diikuti oleh persepsi mahasiswa yang buruk maka kemampuan berbahasa Inggris mahasiswa juga akan semakin rendah. Dengan demikian dapat disimpulkan bahwa kedua variabel self esteem dan persepsi mahasiswa mempunyai pengaruh signifikan baik secara parsial maupun bersama-sama terhadap kemampuan berbahasa Inggris mahasiswa.

\section{KESIMPULAN}

Berdasarkan hasil analisis data penelitian diketahui bahwa: (1) tidak terdapat pengaruh dari self esteem terhadap kemampuan berbahasa Inggris mahasiswa Program Unggulan Politeknik Negeri Jember, (2) terdapat pengaruh yang signifikan dari persepsi mahasiswa terhadap kemampuan berbahasa Inggris mahasiswa Program Unggulan Politeknik Negeri Jember, dan (3) terdapat pengaruh yang signifikan dari self esteem dan persepsi mahasiswa secara bersama-sama terhadap kemampuan berbahasa Inggris mahasiswa Program Unggulan Politeknik Negeri Jember.

Dengan demikian dapat disimpulkan bahwa kemampuan berbahasa Inggris mahasiswa ikut ditentukan oleh faktor persepsi mahasiswa. Semakin baik persepsi mahasiswa pada mata kuliah Bahasa Inggris, maka kemampuan berbahasa Inggris mahasiswa juga akan semakin tinggi.

\section{SARAN}

Berdasarkan kesimpulan penelitian di atas, dapat disarankan kepada para civitas akademika yang meliputi mahasiswa dan dosen, agar menciptakan atmosfer akademis yang kondusif untuk menumbuhkan persepsi positif mahasiswa terhadap mata kuliah Bahasa Inggris dengan cara menumbuhkan kesadaran tentang pentingnya Bahasa Inggris saat ini. Saran kedua ditujukan kepada para pimpinan Politeknik Negeri Jember untuk membuat kebijakan yang dapat mendorong civitas akademika untuk meningkatkan kemampuan berbahasa Inggris dengan cara mengadakan sertifikasi Bahasa Inggris bagi civitas akademika dalam rangka menuju world class university.

\section{DAFTAR PUSTAKA}

Anonymous. Persepsi: Pengertian, Definisi, dan Faktor yang Mempengaruhi. http://bahasa.kompasiana.com/2013/10/20 /persepsi-pengertian-definisi-dan-factoryang-mempengaruhi-600802.html . 2013

Arikunto, Suharsimi. Manajemen Penelitian. Jakarta: Rineka Cipta, 2007.
Cherry, Kendra. What Is Self-Esteem? http://psychology.about.com/od/sindex/f/ what-is-self-esteem.htm. 2013.

Edge, Julian. Essentials of English Language Teaching. New York: Longman, 1999.

Jacobalis, Samsi. Beberapa Teknik Dalam Manajemen Mutu., Universitas Gajahmada, Yogyakarta, 2000.

Khairiyah, Siti.,dkk. Korelasi antara perilaku bullying dan Tingkat SelfEsteem pada Pelajar Dua Buah SMPN di Surabaya. http://journal.unair.ac.id/filerPDF/PERIL AKU\%20BULLYING\%20\%20DAN\%20TINGKAT\%20SELFESTEEM Khairiah.pdf. 2012

Mellia, Christia. "Inner Voice dan Self-Esteem”. MAKARA, Sosial Humaniora, Vol. 11, No. 1, Juni 2007: 37-41

Muntamah, Ummu.,dkk. "Persepsi Mahasiswa Tentang Mutu Pelayanan Pendidikan dan Motivasi Mengikuti Proses Belajar Mengajar". Jurnal Promosi Kesehatan Indonesia Vol. 7 / No. 2 / Agustus 2012

Prasetya, Veronika.,dkk. "Peran Kepuasan Kerja, Self Esteem, Self Efficacy terhadap Kinerja Individual. Jurnal Riset Manajemen dan Akuntansi (JRMA); Vol. 1 No. 1, Februari 2013

Riksayustiana, Yusi.,dkk. Self Esteem. 2008

Schacter, Daniel. Psychology. Worth Publishers. 2011.

Schunk,et.al. translated by Tjo, Ellys. 2012. Motivation in Education, New Jersey: Pearson Education, Inc., 2008

Sugiyono. Metode Penelitian Pendidikan: Pendekatan Kuantitatif, Kualitatif, dan $R \& D$. Bandung: Alfabeta, 2006.

Thanasoulas, Dimitrios. "What is Learner Autonomy and How Can It Be Fostered?", The Internet TESL Journal. 2008.

http://iteslj.org/Articles/ThanasoulasAutonomy.html.

Woolfolk, Anita. Educational Psychology. Boston: Pearson Education, Inc., 2004. 